\title{
ANALISIS DAYA LISTRIK PADA JAHE DALAM BENTUK BUBUR DAN LARUTAN EKSTRAKSI
}

\author{
Fita Widiyatun ${ }^{1}$, Sri Endang Wahyuni ${ }^{1}$, Didik Nur Huda ${ }^{1}$ \\ Program Studi Teknik Informatika, Universitas Indraprasta PGRI \\ Fita.wdy@gmail.com
}

Submitted April 16, 2021; Revised April16, 2021; Accepted August 1, 2021

\begin{abstract}
Abstrak
Energi listrik sangat erat hubungannya dengan kehidupan manusia dewasa ini. Hal itu karena banyak barang elektronik yang dapat difungsikan dengan adanya energi listrik. Semakin banyak jumlah penduduk dan keperluannya akan barang elektronik, maka akan semakin besar pula kebutuhan akan listrik. Karena hal tersebut sangat penting diperlukan adanya kajian tentang energi listrik. Tujuan dari penelitian ini adalah menghitung daya listrik yang tersimpan pada jahe, dalam bentuk bubur dan larutan ekstraksi. Penelitian ini merupakan penelitian eksperimen. Data yang diambil adalah besar tegangan dan arus dengan variasi massa dan jenis jahe. Hasil yang diperoleh dari penelitian ini adalah saat jahe dalam bentuk bubur, daya listrik terbesar pada jahe merah dengan nilai 180,3802 mikroWatt. Sedangkan saat dalam bentuk larutan ekstraksi, nilai terbesar terdapat pada jahe emprit dengan daya 106, 3404 mikroWatt.
\end{abstract}

Kata Kunci : kuat arus listrik, daya listrik, jahe, tegangan

\begin{abstract}
Electrical energy is closely related to human life today. This is because many electronic goods can be used in the presence of electrical energy. The more population and needs for the electronic goods, more greater the needs of electricity. Because this is very important, a study of electrical energy is needed. The purpose of this research is to calculate the electrical power stored in ginger, in the form of slurry and extraction solution. This research is an experimental research. The data taken is the amount of voltage and current with variations in the mass and type of ginger. The results obtained from this study are when the ginger is in the form of slurry, the largest electric power is in red ginger with a value of 180.3802 microWatt. Meanwhile, when it is in the form of extraction solution, the greatest value is found in emprit ginger with a power of 106, 3404 microWatt.
\end{abstract}

Key Words : electric current, electric power, ginger, voltage

\section{PENDAHULUAN}

Di Jaman sekarang, listrik merupakan energi yang keberadaanya diperlukan untuk memenuhi kebutuhan hidup masyarakat. Banyak barang elektronika yang dapat digunakan dengan adanya listrik sebagai energinya. Sebagai contoh handphone, televisi, kipas angin, ac, mesin cuci, kulkas dan masih banyak lagi. Bahkan, Sekarang telah ada mobil yang menggunakan listrik sebagai energinya.

Indonesia merupakan negara yang sangat kaya akan sumber energi. Berbagai macam pembangkit listrik terus diupayakan untuk memenuhi kebutuhan warganya. Mulai dari air, panas dan cahaya matahari, angin, dan lainnya. Telah banyak penelitian yang mengkaji tentang sumber daya - sumber daya alam tersebut sebagai pembangkit listrik untuk dikonversikan menjadi energi listrik [1]-[3]. Dari berbagai macam pembangkit listrik yang telah ada, PLTU yang berbahan dasar batu bara masih mendominasi dengan nilai $48 \%$ dari total kapasitas pembangkit listrik dalam negeri [4].

Pada kenyataannya, meskipun telah banyak pembangkit listrik dan kajian-kajiannya dari berbagai sumber energi, kebutuhan akan energi listrik juga meningkat seraya 
meningkatnya jumlah serta keperluan penduduk dalam menggunakan energi listrik. Untuk itu diperlukan sumber daya yang lainnya, yang dapat diubah atau dikonversi menjadi energi listrik. Dimana sumber daya tersebut ramah terhadap lingkungan.

Pernah dilakukan penelitian tentang kuat arus listrik pada buah jeruk dan mangga yang dikaitkan dengan tingkat keasamannya [5]. Selain itu pernah dilakukan juga penelitian tentang pengaruh penambahan enzim ptyalin pada bio baterai kentang untuk mengahasilkan arus maksimum serta tingkat efektivitasnya [6]. Peneliti belum pernah menemukan tulisan tentang pengukuran daya listrik pada jahe dalam bentuk bubur maupun hasil larutan ekstraksi. Karena hal tersebut, tujuan dari penelitian ini adalah untuk mengetahui besar tegangan dan kuat arus di dalam jahe dalam bentuk bubur maupun hasil larutan ekstraksi. Dengan mengetahui nilai tegangan dan kuat arusnya, maka akan dapat dicari besar daya yang tersimpan pada jahe dalam bentuk bubur maupun dalam bentuk hasil ekstraksi.

Penelitian ini merupakan penelitian eksperimen dan penelitian lanjutan, dimana pernah diteliti tentang daya listrik yang tersimpan pada jahe dalam bentuk rimpang. Hasil yang diperoleh dari penelitian tersebut yaitu nilai daya terbesar terdapat pada jahe Gajah [7]. Jahe merupakan tanaman yang cukup mudah untuk dikembangbiakkan. Selain itu, jahe juga merupakan hasil bumi yang mempunyai banyak manfaat. Terdapat tiga jenis jahe diantaranya jahe merah (Zingiber officinale var rubrum), jahe emprit ( $Z$ officinale var amarum), dan jahe gajah ( $Z$ officinale var officinarum). Jahe mempunyai rasa pedas, dimana rasa pedas dari masing-masing jenis jahe berbedabeda. Dari ketiga jenis jahe di atas, jahe emprit dan jahe merah mempunyai rasa yang lebih pedas apabila dibandingkan dengan jahe gajah. Rasa pedas pada jahe disebabkan karena kandungan oleoresin [8]-[10].

\section{METODE PENELITIAN}

Penelitian ini dilakukan pada semester ganjil 2020/2021, di Laboratorium Pendidikan Fisika, Universitas Indraprasta PGRI Jakarta. Adapun alat dan bahan dalam penelitian ini antara lain jahe merah, jahe emprit, jahe gajah, blender, air, wadah/toples, timbangan, kawat, penjepit buaya, paku baja, paku besi, multimeter, pengaduk, saringan, kabel, dll.

Metode yang dilakukan dalam penelitian ini adalah eksperimen. Tahapan-tahapan penelitian yang dilakukan, seperti ditampilkan pada gambar diagram alir di bawah ini (gambar 1).

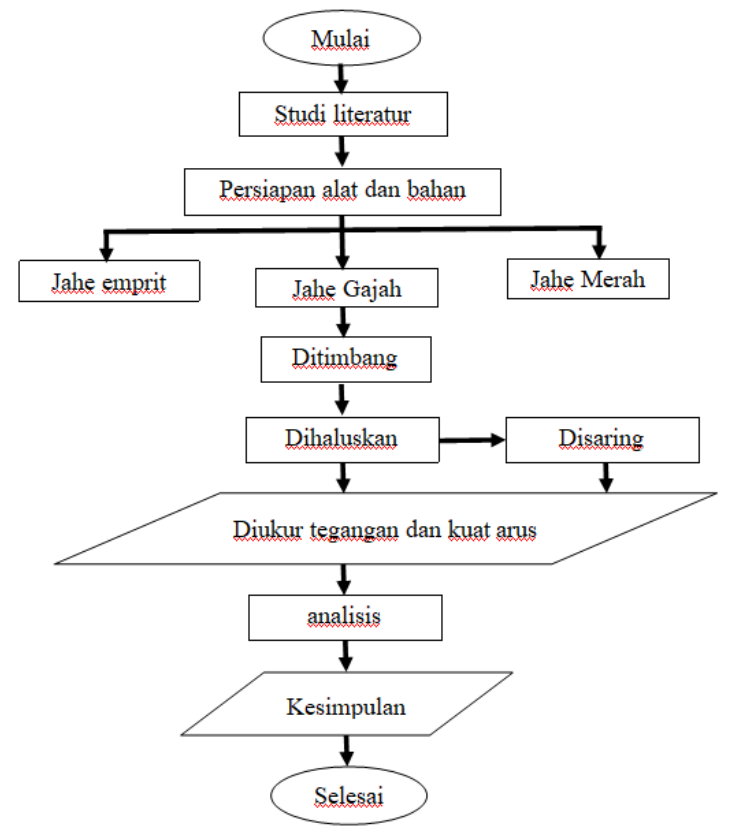

Gambar 1. Diagram Alir Penelitian.

\section{Persiapan dan pengambilan data}

Jahe merah, jahe emprit, dan jahe gajah yang telah diperoleh kemudian dibersihkan dari kotoran atau tanah yang menempel. Selanjutnya, jahe tersebut ditimbang, masing-masing dengan berat 100 gram, 200 gram, dan 300 gram. Setelah 
ditimbang, kemudian diblender sampai halus. Dalam proses pengahalusan, setiap 100 gram jahe ditambahkan dengan $100 \mathrm{ml}$ air. Jahe yang telah dihaluskan dalam bentuk bubur, kemudian diukur besar tegangan dan kuat arusnya menggunakan multimeter dengan rangkaian seperti pada gambar 2. Pengambilan data dilakukan pada masing-masing jenis jahe dengan variasi massa.

Sampel dalam bentuk larutan ekstraksi, hasil jahe yang sudah dihaluskan dalam bentuk bubur tadi kemudian disaring dan diambil airnya. Sedangkan ampasnya disingkirkan. Larutan ekstraksi dari masing-masing jenis jahe ini, kemudian diukur besar tegangan dan kuat arusnya.

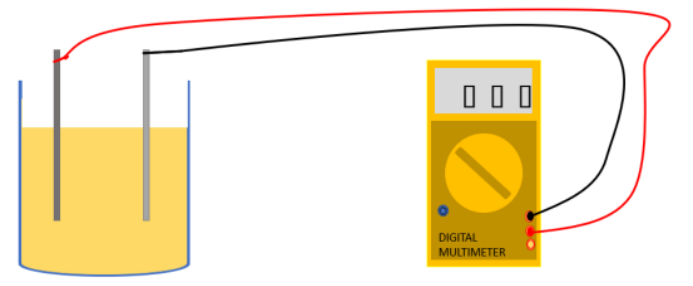

Sumber : Dokumentasi penulis

\section{Gambar 2. Rangkaian Alat dalam Pengambilan Data}

Daya yang tersimpan

Data yang diukur dengan menggunakan multimeter adalah besar tegangan dan arus listrik dari jahe tersebut. Kemudian, dari besar tegangan dan arus listriknya digunakan untuk menghitung besar daya listrik. Besar daya dihitung dengan menggunakan persamaan :

$$
P=V . I
$$

Dengan $P$ adalah daya listrik, $V$ adalah tegangan, dan $I$ adalah arus listrik.

\section{HASIL DAN PEMBAHASAN}

Terdapat tiga macam jenis jahe yang digunakan dalam penelitian ini, diantaranya jahe merah, jahe emprit dan jahe gajah, seperti ditunjukkan pada gambar 3. Jahe tersebut diperoleh dari pasar tradisional di daerah Jakarta Timur. Pengukuran data yang dilakukan terhadap jahe yaitu besar tegangan listrik dan kuat arusnya. Sedangkan sampel dari jahe yang dilakukan pengukuran dalam bentuk bubur dan hasil ekstraksi.

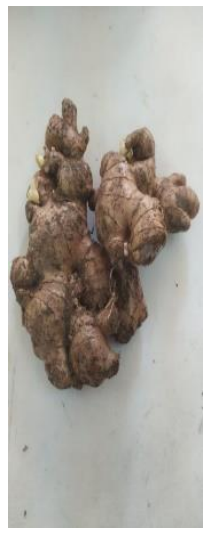

a

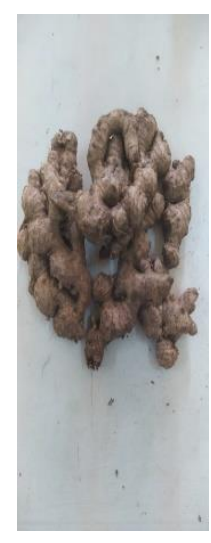

b

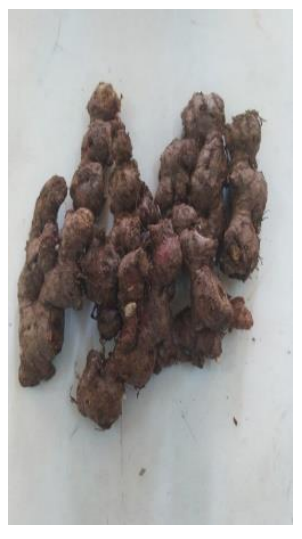

c
Sumber : Dokumentasi penulis

Gambar 3. Kenampakan Bentuk Jahe. a) Jahe Gajah, b) Jahe Emprit, c) Jahe Merah.

\section{Pengukuran daya listrik dalam bentuk bubur}

Jahe yang telah dibersihkan, kemudian dihaluskan dengan menggunakan blender sehingga berbentuk bubur. Bubur tersebut kemudian diukur dengan menggunakan multimeter untuk menentukan besar tegangan dan kuat arusnya. Adapun hasil pengukuran tegangan dan kuat arusnya dari tiga jenis jahe, dengan variasi massa seperti ditunjukkan pada tabel 1 , table 2 , dan tabel 3 di bawah ini.

Tabel 1. Nilai hasil pengukuran pada jahe dalam bentuk bubur untuk massa 100 gram

\begin{tabular}{ccc}
\hline \multirow{2}{*}{ Jenis } & \multicolumn{2}{c}{100 gram } \\
\cline { 2 - 3 } & $\begin{array}{c}\text { Tegangan } \\
\text { (miliVolt) }\end{array}$ & $\begin{array}{c}\text { Arus } \\
\text { (miliAmpere) }\end{array}$ \\
\hline Gajah & 603.0000 & 0.1391 \\
Emprit & 641.4444 & 0.1761 \\
Merah & 695.5556 & 0.1886
\end{tabular}


Tabel 2. Nilai hasil pengukuran pada jahe dalam bentuk bubur untuk massa 200 gram

\begin{tabular}{ccc}
\hline \multirow{2}{*}{ Jenis } & \multicolumn{2}{c}{ 200 gram } \\
\cline { 2 - 3 } & $\begin{array}{l}\text { Tegangan } \\
\text { (milivolt) }\end{array}$ & $\begin{array}{c}\text { Arus } \\
\text { (miliAmpere) }\end{array}$ \\
\hline Gajah & 615.6667 & 0.1561 \\
Emprit & 738.0000 & 0.1300 \\
Merah & 667.3333 & 0.2703 \\
\hline
\end{tabular}

Tabel 3. Nilai hasil pengukuran pada jahe dalam bentuk bubur untuk massa 300 gram

\begin{tabular}{ccc}
\hline \multirow{2}{*}{ Jenis } & \multicolumn{2}{c}{300 gram } \\
\cline { 2 - 3 } & $\begin{array}{c}\text { Tegangan } \\
\text { (miliVolt) }\end{array}$ & $\begin{array}{c}\text { Arus } \\
\text { (miliAmpere) }\end{array}$ \\
\hline Gajah & 692.3333 & 0.1465 \\
Emprit & 759.3333 & 0.1344 \\
Merah & 612.0000 & 0.0994 \\
\hline
\end{tabular}

Berdasarkan data-data tersebut di atas, untuk jenis jahe gajah dan jahe emprit terdapat kenaikkan besar tegangan terhadap massa. Tetapi berbeda dengan jahe merah, terdapat penurunan besar tegangan terhadap kenaikkan massa. Datadata tersebut kemudian dilakukan perhitungan dengan menggunakan persamaan satu (1), sehingga diperoleh besar daya pada masing-masing jahe dengan variasi massa. Dengan menggunakan Microsoft excel dapat dibuatkan gambar grafik daya seperti pada gambar 4..

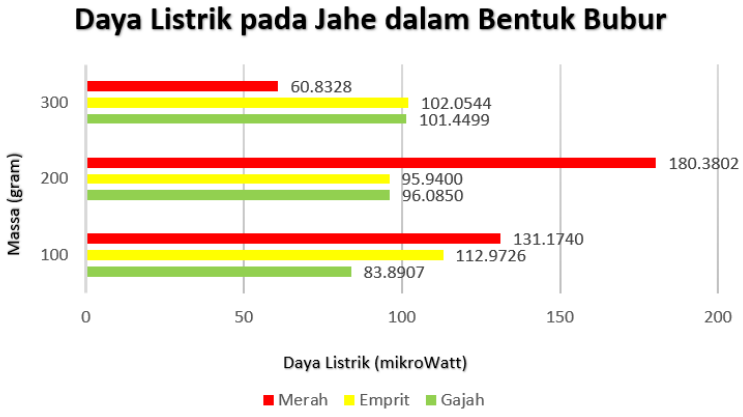

Sumber : Dokumentasi penulis

Gambar 4. Grafik besar daya dari jahe merah, jahe gajah, maupun jahe emprit terhadap variasi massa.

Pada gambar grafik di atas, ditunjukkan bahwa pada massa 100 gram dan 200 gram, besar daya terbesar adalah jahe merah dengan nilai 131,1740 mikroWatt dan 180,3802 mikroWatt. Hanya pada massa 300 gram daya pada jahe merah turun menjadi 60,8328 mikroWatt. Terdapat kenaikkan daya pada jahe Gajah terhadap variasi massa, yaitu 83,8907 mikroWatt (100 gram), 96,0850 mikroWatt (200 gram), dan 101,4499 mikroWatt (300 gram). Sedangkan pada jahe emprit, besar daya terbesar terdapat pada massa 100 gram yaitu 112,9726 mikroWatt, pada massa ke 200 gram terjadi penurunan besar daya menjadi 95,9400 mikroWatt. Pada massa ke 300 gram, terjadi kenaikkan besar daya menjadi 102,0544 mikroWatt.

\section{Pengukuran daya listrik dalam bentuk ekstraksi}

Pengukuran daya listrik dari larutan ekstraksi dilakukan dengan massa jahe 300 gram yang dihaluskan bersamaan dengan $300 \mathrm{ml}$ air. Setelah halus kemudian disaring, dipisahkan antara larutan dengan ampasnya. Pengukuran dilakukan pada larutan dari masing-masing jahe.

Terdapat dua cara pengukuran tegangan dan kuat arus pada saat berbentuk hasil ektraksi jahe. Pertama, pengambilan data tanpa mengaduk larutan ektraksi jahe, dan kedua adalah pengukuran dilakukan sambil 
dengan mengaduk larutan ekstraksi tersebut. Adapun hasil dari pengukuran tengangan dan kuat arus seperti ditunjukkan pada tabel 4 dan tabel 5 di bawah ini.

Tabel 4. Hasil pengukuran larutan ekstraksi Jahe tanpa di aduk

\begin{tabular}{lcc}
\hline \multicolumn{3}{c}{ Pengukuran tanpa diaduk } \\
\hline jenis & $\begin{array}{c}\text { Tegangan } \\
\text { (miliVolt) }\end{array}$ & $\begin{array}{c}\text { Arus } \\
\text { (miliVolt) }\end{array}$ \\
\hline Gajah & 688.0000 & 0.1541 \\
Emprit & 714.3333 & 0.1489 \\
Merah & 682.0000 & 0.1139 \\
\hline
\end{tabular}

Tabel 5. Hasil pengukuran larutan ekstraksi Jahe dengan di aduk

\begin{tabular}{lcc}
\hline \multirow{2}{*}{ jenis } & \multicolumn{2}{c}{ Pengukuran dengan diaduk } \\
\cline { 2 - 3 } & $\begin{array}{c}\text { Tegangan } \\
\text { (miliVolt) }\end{array}$ & $\begin{array}{c}\text { Arus } \\
\text { (miliVolt) }\end{array}$ \\
\hline Gajah & 540.0000 & 0.1208 \\
Emprit & 657.0000 & 0.1087 \\
Merah & 477.3333 & 0.0942
\end{tabular}

Data di atas menunjukkan bahwasannya baik pengukuran tegangan maupun kuat arus listrik saat larutan ekstraksi tidak diaduk mempunyai nilai yang lebih besar dari pada pengukuran dengan melakukan pengadukkan. Hal ini bisa terjadi karena saat dilakukan pengadukan maka terjadi pergerakan partikel sehingga berpengaruh terhadap besar beda potensialnya dan kuat arusnya. Pernah dilakukan penelitian tentang sifat biolistrik lengkeng diamond river dengan melakukan pengukuran beda potensial kelistrikan dan diperoleh hasil $6,2 \mathrm{mV}$ sampai $21 \mathrm{mV}$ pada saat terjadi hujan dan $14,5 \mathrm{mV}$ sampai $19,8 \mathrm{mV}$ saat cuaca tidak hujan [11]. Jika dibandingkan dengan data tersebut, nilai tegangan pada tabel 1 dan 2 mempunyai nilai yang jauh lebih besar. Dari data-data pada tabel 1 dan 2 di atas, kemudian dimasukkan ke dalam persamaan (1), sehingga diperoleh nilai daya yang ditunjukkan seperti pada gambar 5 di bawah ini.

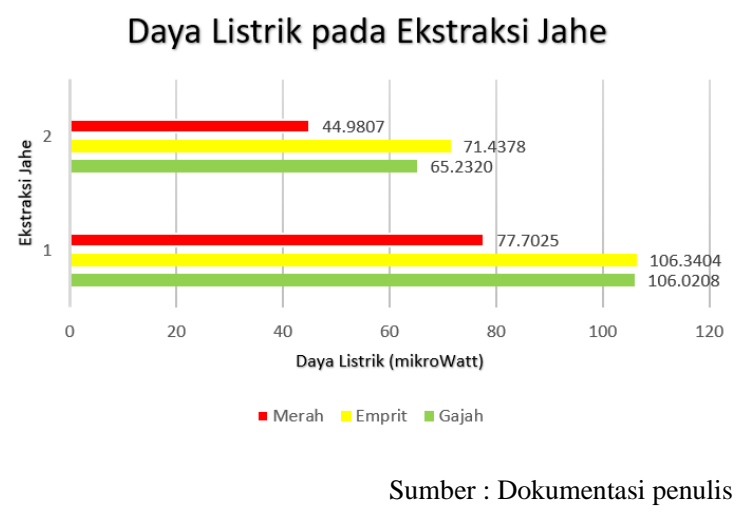

Picture 5. Besar daya listrik. 1)

Pengukuran tanpa di aduk, 2) Pengukuran dengan diaduk.

Berdasarkan gambar di atas, ditunjukkan bahwa besar daya pada jahe merah, jahe emprit, maupun jahe gajah saat pengukuran tanpa diaduk mempunyai daya yang lebih besar daripada pengukuran larutan sambil di aduk. Nilai daya terbesar, baik dilakukan pengadukan maupun tidak diaduk dimiliki oleh jahe emprit, yaitu 106,3404 mikroWatt (tanpa diaduk) dan 71,4378 mikroWatt (dengan diaduk). Dan nilai terendah dari ketiga jahe tersebut, baik dilakukan pengukuran dengan diaduk maupun tidak diaduk, dimiliki oleh jahe merah dengan nilai 77,7025 mikroWatt (tanpa diaduk) dan 44,9807 mikroWatt (dengan diaduk).

Hasil ini, kemudian dibandingkan dengan perhitungan daya untuk hasil pengukuran pada saat berbentuk bubur dengan massa 300 gram pada tabel di bawah ini, terlihat persamaan grafik tertinggi nilainya dimiliki oleh jahe emprit, dan terendah dimiliki oleh jahe merah. Nilai daya jahe gajah dan jahe emprit saat berbentuk bubur jahe, tidak berbeda jauh dengan hasil pengukuran saat berbentuk larutan ekstraksi dengan pengukuran tanpa diaduk. Selisih nilainya tidak lebih dari 5 mikrowatt. Sedangkan jika dibandingkan antara pengukuran saat berbentuk bubur 
dan pengukuran dengan pengadukan mempunyai selisih sekitar 30 mikroWatt untuk jahe emprit dan 36 mikroWatt untuk jahe Gajah. Sedangkan untuk jahe merah saat melakukan perhitungan dalam bentuk bubur nilainya hampir ditengah-tengah antara saat perhitungan pengukuran tanpa diaduk maupun dengan diaduk. Tetapi, dari data pada gambar di atas dapat ditunjukkan nilai daya terbesar baik untuk jahe gajah, jahe emprit, maupun jahe merah pengukuran saat tanpa diaduk lebih besar jika dibandingankan dengan pengukuran sambil diaduk ataupun saat berbentuk bubur.

\section{SIMPULAN}

Berdasarkan penelitian yang telah dilakukan, diperoleh hasil bahwa saat dilakukan pengukuran daya jahe dalam bentuk bubur, diperoleh nilai tertinggi sebesar 180,3802 mikroWatt pada jahe merah 200 gram. Sedangkankan pada larutan ekstraksi jahe, diperoleh nilai daya lebih saat pengukuran tanpa diaduk baik untuk jahe emprit, jahe merah, maupun jahe gajah. Dengan nilai terbesar pada jahe emprit sebesar 106,3404 mikroWatt.

\section{DAFTAR PUSTAKA}

[1] Syaikhurrohman, "Studi Perencanaan Sistem Pembangkit Listrik Tenaga Microhydro (PLTMH) pada Sungai Kalimaja Dusun Kedondong Rame Desa Ruguk Kecamatan Ketapang Kabupaten Lampung Selatan," J. Tek. Mesin, vol. 4, no. 1, pp. 1-34, 2016.

[2] D. A. Widodo, Suryono, and T. A, "Pemberdayaan Energi Matahari Sebagaai Energi Listrik Lampu Pengatur Lalu Lintas," J. Tek. Elektro, vol. 2 , no. $2,2010$.

[3] T. Tjahjono and E. Widodo, "Penggunaan Energi Angin dan Energi Matahari Sebagai Sumber Listrik dengan Sistem Hybrid," Semin. Nas. Sains dan Teknol. Fak. Tek. UNWAHAS Ke-2 2011, 2011, [Online]. Available: https://publikasiilmiah.unwahas.ac.id/in dex.php/PROSIDING_SNST_FT/articl e/view/269/259.

[4] I. Sulistiyawati, N. L. Rahayu, and F. S. Purwitaningrum, "Produksi Biolistrik Menggunakan Microbial Fuel Cell (MFC) Lactobacillus bulgaricus dengan Substrat Limbah Tempe dan Tahu," Biosf. A Sci. J., vol. 37, no. 2, pp. 112117, 2020, doi: 10.20884/1.mib.2020.37.2.1147.

[5] H. Kholida and Pujayanto, "Hubungan Kuat Arus Listrik dengan Keasaman Buah Jeruk dan Mangga," Pros. Semin. Nas. Fis. dan Pendidik. Fis., vol. 6, no. 1, 2015.

[6] S. Pamungkas, "Kentang Sebagai Bio Listrik Dengan Penambahan Enzim Ptialin Sebagai Pengoptimal Arus," PSEJ (Pancasakti Sci. Educ. Journal), vol. 2, no. 1, pp. 48-55, 2017, doi: 10.24905/psej.v2i1.658.

[7] S. E. Wahyuni, F. Widiyatun, and D. N. Huda, "Studi Awal Analisis Variasi Massa Jahe Terhadap Daya Listrik," Newton-Maxwell J. Phys., vol. 1, no. 1, pp. 1-6, 2020.

[8] E. D. Purwakusumah, M. Rafi, U. D. Safitri, W. Nurcholis, and M. A. Z. Adzkiya, "Identifikasi dan Autentikasi Jahe Merah Menggunakan Kombinasi Spektroskopi FTIR dan Kemometrik," J. Agritech, vol. 34, no. 01, pp. 82-87, 2014, [Online]. Available: http://dx.doi.org/10.22146/agritech.952 6.

[9] L. Kurniasari, I. Hartati, R. D. Ratnani, and I. Sumarni, "Kajian Ekstraksi Minyak Jahe Menggunakan Microwave Assisted Extraction (Mae), Momentum, vol. 4, no. 2, pp. 47-52, 2008.

[10] S. Hartuti and Muhammad Dani Supardan, "Optimasi Ekstraksi Gelombang Ultrasonik untuk Produksi Oleoresin Jahe (Zingiber officinale Roscoe) Menggunakan Response Surface Methodology (RSM)," Agritech, vol. 33, no. 4, pp. 415-423, 2013, doi: 10.22146/agritech.9537.

[11] H. A. Notonegoro, R. Lusiani, and N. Firdaus, "Karakterisasi Sifat Biolistrik 
Lengkeng Diamond River (Dimocarpus

Longan ) Tabulampot Terhadap Perbedaan Cuaca Hujan dan Tidak Hujan," Pros. Konfrensi Nas. Eng. Hotel IV, pp. 123-127, 2013, doi: 10.13140/RG.2.1.4297.6801. 